\title{
Effect of Gender and Regions on Determinants of Digital Transformation Adoption in Creative Services
}

\author{
Trieu Van Hai TRAN ${ }^{1 *}$ \\ ${ }^{1}$ Ph.D. student (Management and Economics), Faculty of Management and Economic, Tomas Bata University in Zlín, \\ Mostní 5139, 76001 Zlín, Czech Republic, Email: van_hai@utb.cz \\ * Corresponding Author
}

Received: 05.11.2021 Accepted: 18.12.2021 $\quad$ Published: 01.02.2022 $\quad$ DOI: 10.47750/QAS/23.186.05

\begin{abstract}
The area of digital transformation is attracting considerable interest due to the current trend of digital transformation being deployed around industries in the world. Many researchers have addressed the issue of technology acceptance in various industries; however, the area of digital transformation along with the demographic characteristics of creative services has not been explored, especially in the context of Vietnam. This study aims to clarify the influence on the determinants of adoption of digital transformation based on gender and region and is the first experiment to survey in creative services in Vietnam. The methodology is primarily derived from the technology, organization, and environment framework, and uses analysis of variance, independent sample $t$-test, and multivariate linear regression for investigation; further details on the adopted methodology can be found in this paper. The results reported here provide further evidence for the value of gender and region in the decision of digital transformation adoption and their impact on the determinants of digital transformation. This work has presented a background method for the investigation of creative companies in the context of creative services in Vietnam. However, the findings might be only representative of the characteristics of selected demographics and creative services in Vietnam, so additional studies are needed on other demographic factors and areas.
\end{abstract}

Keywords: Digital transformation, creative industries, creative companies, TOE framework, analysis of variance, independent sample $t$-test, and multivariate linear regression.

\section{Introduction}

The creative economy is not only the vital role for the national economy, but also other industries in Vietnam, it can contribute to growth, prosperity, and provide many employment opportunities. According to the Creative Industries Classification (UNCTAD, 2008), creative services are considered as a subsector in creative industries. Creativity and innovation are a key source for the knowledge economy, the foundation for modern technology change, the competitive edge in creative companies, and the domestic economy. Especially in the context of globalization, Vietnam is being evaluated for many opportunities for the development of the creative economy due to its geographical location, economy, and culture; furthermore, the benefit of enlargement is not needed to exploit natural resources and invest so much in transportation infrastructure, while the information communication technology (ICT) infrastructure is appropriate for evolution. However, to refer to the growth of creative industries in general and in specific to creative services, the most essential factor is the digital transformation in creative companies according to the current trend of the industry 4.0 era. The useful advantages of digital transformation can certainly be demonstrated as the integration of digital technology in business, the improvement of the business model, the enhancement of operation efficiency, and the approach of more potential consumers. In fact, most empirical studies applied technology acceptance theory (Davis, 1989; Tornatzky and Fleischer, 1990) and demographic characteristics for investigation. For example, Ritz et al. (2019) provided a detailed analysis of the adoption of digital marketing at the management level in small businesses, and Al Hadwer et al. (2021) studied the adoption of cloud-based technologies. Porter and Donthu (2006) investigated the perspective of internet use based on factors such as education, age, race, and income. Similar to the study by Palakurthi (2011), the research also explored the use of radio frequency identification derived from gender, income, and education level. From the issues analyzed, it can be seen that the growth of the creative economy must start from the inner development of each creative firm in Vietnam. To do this, however, they have to apply new science and technology to innovate businesses. Therefore, this article provides evidence of the adoption of digital transformation related to creative services by conducting an empirical study in the context of creative services in Vietnam. In addition, this study also provides key information on creative companies based on factors that affect their digital transformation. The next section considers the theoretical background and research hypotheses; Section 3 presents the methodology and Section 4 discusses the results; the last section concludes the study. 


\section{Theoretical background and research hypotheses}

\subsection{Theoretical background}

The importance of development in creative industries is now recognized, in which it contributes to developing the economy and enriching the country. Moreover, creative industries create the coherence between countries through many cooperation programs to expand creative products and services not only domestic but also international. More especially, creative services are one of the creative industries according to the classification of the United Nations Conference on Trade and Development (UNCTAD, 2008), and they also play an equally significant role in contributing to the overall growth of the nation. To achieve success, however, each company must take opportunities and apply modern technology from the fourth industrial revolution, especially digital technology, depending on its business environment; thus, digital transformation is a core strategic issue for the company, especially creative companies in creative services. The most realized benefits of digital transformation help businesses reduce operational costs, increase employee productivity, reach more clients, and improve organizational competitiveness.

In fact, many practical studies conducted in various industries, their character being the application of relevant technology adoption theories for exploration, such as the technology acceptance model (TAM) of (Davis, 1989), the technology, organization, and environment (TOE) framework of (Tornatzky and Fleischer, 1990), and especially the role of demographic variables for technology acceptance. Among empirical investigations according to the research area, the typical study by Akman and Rehan (2016) provided the most indepth analysis of the determinants of the adoption of mobile commerce and services in the workforce, and the findings showed that perspectives are affected by experience, gender, and organizations classified into the public and private sectors. Al Hadwer et al. (2021) used the TOE framework for their study according to cloud-based technology adoption; the study results revealed that organizational perspectives are affected by crucial elements, including cloud complexity, competitive pressure, support of top management, and relative advantage. However, Ritz et al. (2019) conversely proved that the advantages of technology do not have to be a priority factor for the decision on the adoption of digital marketing at the management level in small businesses. In their widely acclaimed work, Ullah et al. (2021) considered threats to the sustainable management of smart cities, the TOE framework helped them identify risks consisting of management of public Internet, user safety, internet of things networks, security of user data, cloud management, surroundings of smart city, as well as its management and security.

An interesting study by Liu and Guo (2017), particularly investigating male and female college students on the adoption of mobile computing devices based on the TAM model, the analysis indicated that the acceptance of male students was only derived from the benefits of social and perceived usefulness while female students included five factors such as benefits of social, perceived usefulness, perceived ease of use, trust and perceived financial cost. Similarly, Naqvi et al. (2019) also organized a realistic exploration between demographic factors and the TAM model; The study results showed that there is a particular relationship between not only perceived usefulness but also demographic characteristics in the plan for using social networking sites. On the contrary, the study by Chen et al. (2002) proved that perceived usefulness did not impact the behavior intention of the online consumer in their research. Furthermore, an analysis by Porter and Donthu (2006) found that demographic characteristics, such as education, age, race, and income, have a significant effect on the consumer's perspective of using the Internet through the empirical study of attitude-based determinants of Internet use. A recent study by Chatterjee et al. (2021) combined the TOE framework and the TAM model to investigate artificial intelligence adoption in enterprises of production and manufacture, they found that factors including the readiness of the organization, compatibility of the organization, partner support for perceived use are not an insignificant effect on firms.

In addition, there are also many other studies in line with demographic attributes. An interesting example is the perception of customers about the features of a fashion website; the findings highlighted demographic variables including income, occupation, age, education, gender, and marital status, which had an essential effect on the attitudes and intentions of customers related to the characteristics of a fashion website such as communication, community, connection, content, customization, and commerce (Kwon et al., 2007). However, the results of Aluri and Palakurthi (2011) differ from those obtained by Kwon et al. (2007), in which gender, income, and education level did not influence the consumer perspective for using radio frequency identification in the hotel industry, except for age. Especially, Harris et al. (2016) studied the wishes of clients about banking technologies among age groups and found modern technologies which are interested in all ages, but younger consumers are more excited. Furthermore, RamírezCorrea et al. (2019) recognized that the technology readiness index dimension and online shopping have a relationship with gender and generation. Chawla and Joshi (2020) provided a detailed analysis of the adoption of mobile wallets established by age and gender; as a result, younger clients and male users have more effect on other ages and female users on perceptions of mobile wallet adoption.

Despite interest in theories of technology acceptance and demographic characteristics, no studies have considered demographic variables, such as gender and region, which are related to the adoption of digital transformation in the context of creative service areas in Vietnam. Having a practical study in this area will be appropriate for the current trend of digital transformation of many industries in Vietnam; As a result, the results of the study advance to enrich research areas, as well as to recognize the actual impact on the adoption of digital transformation by companies in the creative service field.

\subsection{Research hypotheses}

This study extends the research of Trieu and Pavelková (2020), so an empirical study was conducted in companies operating in Vietnam's creative services based on their theoretical research framework in the creative industries. 


\section{GENERAL MANAGEMENT}

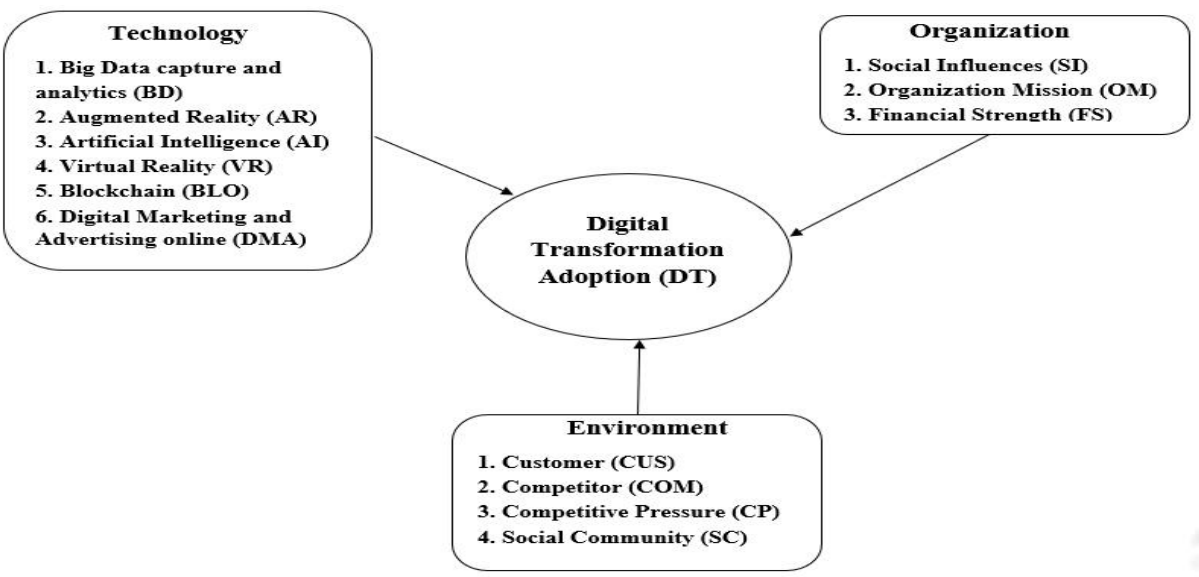

Figure 1: Proposed Research Model

Source: Own study and Trieu and Pavelková (2020)

From the above analysis of the literature review, furthermore, this research combines the research model (Trieu and Pavelková, 2020) to propose the research model (Fig. 1) and research hypotheses as follows:

$\mathrm{H} 1$ : There is a statistically significant difference in gender for the adoption of digital transformation.

$\mathrm{H} 2$ : There is a statistically significant difference in regions for the adoption of digital transformation.

\section{Methodology}

The main survey questionnaire was designed and sent to the management level of creative companies in Vietnam's creative industries for data collection, and the survey had been in place for ten months and was completed in July 2021. Especially,
UNCTAD (2008) classifies creative services, which are one of the creative industries including design, creative services, new media, audiovisuals, performing arts, traditional cultural expressions, culture sites, visual arts, publishing, and printed media; thus, the collected data for creative services were also in the main investigation.

As a result, the creative services had 164 respondents out of 674 responses in the creative industries. As highlighted in Table 1, most of the respondents were from Ho Chi Minh City and Hanoi City, which are the two largest cities in Vietnam, and have an educational level of $75.0 \%$ for bachelors and $20.1 \%$ for masters; similarly, the male response reached $75.6 \%$ compared to females. The survey was also expanded for many job titles, in which two titles had the highest response, such as middle management at $28.7 \%$ and owner at $20.1 \%$.

\begin{tabular}{|c|c|c|c|c|c|}
\hline \multicolumn{2}{|c|}{ 1. Gender } & \multicolumn{2}{|c|}{ 2. Location of companies } & \multicolumn{2}{|c|}{ 3. Educational qualifications } \\
\hline Male & $124(75.6 \%)$ & Hanoi city & $43(26.2 \%)$ & Highschool diploma & $8(4.9 \%)$ \\
\hline \multirow[t]{2}{*}{ Female } & $40(24.4 \%)$ & Ho Chi Minh city & $102(62.2 \%)$ & Bachelor's degree & $123(75.0 \%)$ \\
\hline & & Others & $19(11.6 \%)$ & Master's degree & $33(20.1 \%)$ \\
\hline \multicolumn{3}{|c|}{ 4. Company size (people) } & \multicolumn{3}{|l|}{ 5. Job titles } \\
\hline \multicolumn{2}{|c|}{$1-50$} & $62(37.8 \%)$ & \multicolumn{2}{|c|}{ Owner } & $33(20.1 \%)$ \\
\hline \multicolumn{2}{|l|}{$51-100$} & $58(35.4 \%)$ & \multicolumn{2}{|c|}{ Chief executive officer (CEO) } & $22(13.4 \%)$ \\
\hline \multicolumn{2}{|l|}{$101-500$} & $25(15.2 \%)$ & \multicolumn{2}{|c|}{ Chief financial officer (CFO) } & $8(4.9 \%)$ \\
\hline \multicolumn{2}{|c|}{$501-1000$} & $11(6.7 \%)$ & \multicolumn{2}{|c|}{ Chief technology officer (CTO) } & $19(11.6 \%)$ \\
\hline \multicolumn{2}{|c|}{1001 and 5000} & $4(2.4 \%)$ & \multicolumn{2}{|c|}{ Chief digital officer (CDO) } & $8(4.9 \%)$ \\
\hline \multirow{3}{*}{\multicolumn{2}{|c|}{5001 and more }} & $4(2.4 \%)$ & \multicolumn{2}{|c|}{ Chief information officer $(\mathrm{ClO})$} & $13(7.9 \%)$ \\
\hline & & & \multicolumn{2}{|c|}{ Middle managers } & $47(28.7 \%)$ \\
\hline & & & \multicolumn{2}{|l|}{ Others } & $14(8.5 \%)$ \\
\hline
\end{tabular}

Table 1: Demographics of the respondents Source: Own study

Furthermore, this study also uses the multivariate regression model based on the proposed research model (Fig. 1) to examine the effect of gender and region on the determinants of the adoption of digital transformation in creative services as follows:

$\mathrm{DT}=\alpha 0+\alpha 1^{*} \mathrm{BD}+\alpha 2^{*} \mathrm{AR}+\alpha 3^{*} \mathrm{Al}+\alpha 4^{*} \mathrm{VR}+\alpha 5^{*} \mathrm{BLO}+$ $\alpha 6^{*} \mathrm{DMA}+\alpha 7^{*} \mathrm{SI}+\alpha 8^{*} \mathrm{OM}+\alpha 9^{*} \mathrm{FS}+\alpha 10^{*} \mathrm{CUS}+\alpha 11^{*} \mathrm{COM}+$ $\alpha 12^{*} \mathrm{CP}+\alpha 13^{\star} \mathrm{SC}+\varepsilon$.

(1)

The measurement of dependent variable (DT) and predictor variables (AR, AI, VR, BLO, DMA, SI, OM, FS, CUS, COM, CP, and SC) was determined in previous studies (Tripopsakul, 2018; Chandra and Kumar, 2018; Venkatesh et al., 2003; Karatepe and Aga, 2016; Mckinnie, 2016; Hwang et al., 2016). Data analysis using the Statistical Package for Social Sciences (SPSS) version 25 with examination procedures comprises the following steps, such as independent sample t-test, analysis of variance, Cronbach's alpha, exploratory factor analysis, Pearson's test, and multivariate regression analysis.

\section{Results and Discussion}

\subsection{Independent sample t-test}

In Table 2, it can be observed that the p-value of Levene's test was greater than $5 \%$ and the $p$-value (2-tailed) in the part of 


\section{GENERAL MANAGEMENT}

the assumed equal variances was not less than $5 \%$ as well. Therefore, the null hypothesis is accepted, so the hypothesis $(\mathrm{H} 1)$ is rejected. In other words, there is no statistically significant difference in gender groups for the adoption of digital transformation in Vietnam's creative services.

\begin{tabular}{|c|c|c|c|c|c|c|}
\hline & \multicolumn{2}{|c|}{ Levene's test } & \multicolumn{4}{|c|}{ T-test for Equality of Means } \\
\hline & $\mathrm{F}$ & P-value & $\mathrm{t}$ & df & P-value (2-tailed) & Mean Difference \\
\hline $\begin{array}{l}\text { Equal Variances } \\
\text { assumed }\end{array}$ & 1.699 & 0.194 & -0.023 & 162 & 0.981 & -0.0046 \\
\hline $\begin{array}{l}\text { Equal Variances } \\
\text { not assumed }\end{array}$ & & & -0.029 & 101.535 & 0.977 & -0.0046 \\
\hline
\end{tabular}

Table 2: Independent sample test of the adoption of digital transformation based on gender Source: Own study

\subsection{Analysis of variance}

Table 3 summarizes the results of the one-way ANOVA test. Because the Levene test was not significant at $5 \%$, the analysis of variance was used in the next step. As a result, the $p$-value of the variance analysis was greater than $5 \%$, which means that there is no statistically significant difference in the adoption of digital transformation between the region groups in the creative services of Vietnam and the hypothesis $(\mathrm{H} 2)$ is eliminated.

\begin{tabular}{|c|c|c|c|c|}
\hline \multicolumn{5}{|c|}{ Part A: Test of homogeneity of variances } \\
\hline & Levene statistic & df1 & df2 & P-value \\
\hline Based on Mean & 0.066 & 2 & 161 & 0.936 \\
\hline \multicolumn{5}{|c|}{ Part B: Result of Variance Analysis } \\
\hline & Sum of Squares & $\mathrm{df}$ & Mean Square & P-value \\
\hline Between Groups & 0.621 & 2 & 0.31 & 0.77 \\
\hline Within Groups & 193.52 & 161 & 1.20 & \\
\hline Total & 194.14 & & & \\
\hline
\end{tabular}

Table 3: One-way ANOVA test of the adoption of digital transformation based on region Source: Own study

\subsection{Reliability test}

The results of Cronbach's alpha analysis showed that three of the 14 variables were not reliable because their Cronbach alpha coefficients were less than 0.7 (Hair et al., 2010). Thus, these variables, such as BLO, FS, and SC, were rejected from equation (1).

\subsection{Exploratory Factor Analysis}

After completing Cronbach's alpha analysis, the next step is exploratory factor analysis using the method of principal components with varimax rotation. Interestingly, ten factors of independent variables were extracted in Table 4, and most factor loadings were greater than 0.5 .

\begin{tabular}{|c|c|c|c|c|c|c|c|c|c|c|}
\hline \multicolumn{11}{|c|}{ Dependent variable } \\
\hline \multicolumn{3}{|c|}{ Observed variables } & \multirow{2}{*}{\multicolumn{2}{|c|}{$\frac{\text { DT2 }}{898}$}} & \multirow{2}{*}{\multicolumn{2}{|c|}{$\begin{array}{l}\text { DT4 } \\
892\end{array}$}} & \multicolumn{2}{|l|}{ DT3 } & \multicolumn{2}{|c|}{ DT1 } \\
\hline \multicolumn{3}{|c|}{ Factor loadings } & .898 & & .892 & & \multicolumn{2}{|l|}{.871} & \multicolumn{2}{|c|}{.835} \\
\hline \multirow{2}{*}{$\begin{array}{l}\text { Observed } \\
\text { variables }\end{array}$} & \multicolumn{10}{|c|}{ Independent variables - Factor loadings } \\
\hline & 1 & 2 & 3 & 4 & 5 & 6 & 7 & 8 & 9 & 10 \\
\hline CP2 & .866 & & & & & & & & & \\
\hline CP3 & .786 & & & & & & & & & \\
\hline CP1 & .731 & & & & & & & & & \\
\hline CP4 & .704 & & & & & & & & & \\
\hline $\mathrm{SI} 2$ & & .841 & & & & & & & & \\
\hline SI1 & & .803 & & & & & & & & \\
\hline $\mathrm{SI3}$ & & .637 & & & & & & & & \\
\hline $\mathrm{SI} 4$ & & .605 & & & & & & & & \\
\hline AR1 & & & .845 & & & & & & & \\
\hline AR2 & & & .823 & & & & & & & \\
\hline AR3 & & & .818 & & & & & & & \\
\hline $\mathrm{OM} 2$ & & & & .799 & & & & & & \\
\hline OM1 & & & & .777 & & & & & & \\
\hline OM3 & & & & .766 & & & & & & \\
\hline $\mathrm{Al} 2$ & & & & & .836 & & & & & \\
\hline $\mathrm{Al} 3$ & & & & & .830 & & & & & \\
\hline Al1 & & & & & .794 & & & & & \\
\hline CUS3 & & & & & & .820 & & & & \\
\hline
\end{tabular}




\section{GENERAL MANAGEMENT}

\begin{tabular}{|l|l|l|l|l|l|l|l|l|l|l|}
\hline CUS1 & & & & & & .782 & & & & \\
\hline CUS2 & & & & & & .765 & & & & \\
\hline COM1 & & & & & & & .870 & & & \\
\hline COM2 & & & & & & & .840 & & & \\
\hline COM3 & & & & & & & .758 & & & \\
\hline DMA2 & & & & & & & & .832 & & \\
\hline DMA3 & & & & & & & & .795 & & \\
\hline DMA1 & & & & & & & & .779 & & \\
\hline VR1 & & & & & & & & & .818 & \\
\hline VR2 & & & & & & & & & .768 & \\
\hline VR3 & & & & & & & & & .705 & \\
\hline BD2 & & & & & & & & & & .808 \\
\hline BD3 & & & & & & & & & & .776 \\
\hline BD1 & & & & & & & & & & .689 \\
\hline
\end{tabular}

Table 4: Results of exploratory factor analysis Source: Own study

Furthermore, other values of the dependent variable (KMO $=0.838$, Chi-square $=390.21, \mathrm{df}=6, \mathrm{p}$-value $=0.000$, eigenvalues $=3.058$, cumulate $=76.43 \%$ ) and predictor variables $(\mathrm{KMO}=0.846$, Chi-square $=3389.62, \mathrm{df}=496, \mathrm{p}$ value $=0.000$, eigenvalues $=1.008$, cumulate $=78.48 \%$ ) were also relevant, in which the $\mathrm{p}$-value was significant at $5 \%, \mathrm{KMO}$ values were not less than 0.5 and eigenvalues were larger than 1 ; therefore, all values are appropriate for the study of Hair et al.
(2010).

\subsection{Pearson test}

According to a study by Schober et al. (2018), the 95\% confidence interval is between 0.03 and 0.7 , so the correlation coefficient is greater than or equal to 0.7 , which happens to be a strong correlation between variables.

\begin{tabular}{|c|c|c|c|c|c|c|c|c|c|c|c|}
\hline & BD & AR & Al & $\begin{array}{l}\text { VR } \\
\end{array}$ & DMA & SI & OM & CUS & COM & CP & DT \\
\hline BD & 1 & & & & & & & & & & \\
\hline AR & $.34^{* *}$ & 1 & & & & & & & & & \\
\hline Al & $.45^{\star \star}$ & $.30^{* *}$ & 1 & & & & & & & & \\
\hline $\begin{array}{l}\text { VR } \\
\end{array}$ & $.40^{\star \star}$ & $.48^{* *}$ & $.26^{* *}$ & 1 & & & & & & & \\
\hline DMA & $.43^{\star *}$ & $.43^{\star *}$ & $.29^{* *}$ & $.51^{* \star}$ & 1 & & & & & & \\
\hline SI & $.42^{\star \star}$ & $32^{* *}$ & $.48^{* *}$ & $.38^{\star \star}$ & $47^{\star \star}$ & 1 & & & & & \\
\hline OM & $.35^{\star \star}$ & $.26^{\star *}$ & $36^{* *}$ & $26^{\star *}$ & $30^{* *}$ & $.32^{* *}$ & 1 & & & & \\
\hline CUS & $.33^{* *}$ & $26^{* *}$ & $.38^{* *}$ & $.27^{* *}$ & $29^{* *}$ & $39^{* *}$ & $.59^{* *}$ & 1 & & & \\
\hline COM & $.21^{\star *}$ & $.30^{* *}$ & $.36^{* *}$ & $28^{* *}$ & $24^{\star \star}$ & $.23^{* *}$ & $.35^{\star *}$ & $.43^{* *}$ & 1 & & \\
\hline CP & $.41^{\star \star}$ & $27^{\star \star}$ & $.31^{* *}$ & $.34^{\star *}$ & $.36^{* *}$ & $.44^{\star *}$ & $.38^{* *}$ & $.41^{* *}$ & $19^{\star \star}$ & 1 & \\
\hline DT & $49^{* *}$ & $.34^{* *}$ & $.61^{* *}$ & $.38^{* *}$ & $.36^{* *}$ & $.45^{* *}$ & $.60^{* *}$ & $.58^{* *}$ & $.52^{* *}$ & $.36^{* *}$ & 1 \\
\hline
\end{tabular}

Table 5: Pearson test for dependent and independent variables Source: Own study

As can be seen in Table 5 , each pair of variables was significant at $5 \%$, and the correlation coefficients were also less than 0.7 , which means that a multicollinearity phenomenon does not occur.

\subsection{Multivariate regression analysis}

\begin{tabular}{|c|c|c|c|c|c|c|}
\hline \multirow[t]{2}{*}{$\begin{array}{l}\text { Dependent } \\
\text { variable (DT) }\end{array}$} & \multicolumn{2}{|c|}{$\begin{array}{l}\text { Full Sample } \\
\text { (Obs. = 164) }\end{array}$} & \multicolumn{2}{|c|}{$\begin{array}{l}\text { Male } \\
\text { (Obs. = 124) }\end{array}$} & \multicolumn{2}{|c|}{$\begin{array}{l}\text { Female } \\
\text { (Obs. = 40) }\end{array}$} \\
\hline & SC & $\mathrm{P}$-value & SC & $\mathrm{P}$-value & SC & $\mathrm{P}$-value \\
\hline Const. $(a 0)$ & & 0.16 & & $0.014^{\star *}$ & & 0.291 \\
\hline $\mathrm{BD}(\alpha 1)$ & 0.147 & $0.017^{\star \star *}$ & 0.064 & 0.310 & 0.187 & 0.276 \\
\hline AR $(\alpha 2)$ & -0.015 & 0.789 & 0.046 & 0.441 & -0.295 & 0.136 \\
\hline $\mathrm{Al}(\alpha 3)$ & 0.289 & $0.00^{* * *}$ & 0.342 & $0.00^{* \star *}$ & 0.184 & 0.437 \\
\hline VR (a4) & 0.074 & 0.226 & 0.084 & 0.177 & 0.041 & 0.824 \\
\hline DMA (a5) & -0.003 & 0.967 & -0.051 & 0.428 & 0.047 & 0.789 \\
\hline SI (a6) & 0.037 & 0.552 & 0.102 & 0.104 & -0.286 & 0.203 \\
\hline $\mathrm{OM}(\alpha 7)$ & 0.235 & $0.00^{* * *}$ & 0.306 & $0.00^{* \star *}$ & 0.009 & 0.963 \\
\hline CUS ( $\alpha 8)$ & 0.202 & $0.00^{\star * \star}$ & 0.121 & $0.063^{*}$ & 0.585 & $0.00^{\star * *}$ \\
\hline COM (a9) & 0.221 & 0.000 & 0.209 & $0.00^{* \star *}$ & 0.100 & 0.570 \\
\hline CP (a10) & -0.045 & 0.445 & -0.017 & 0.762 & 0.039 & 0.862 \\
\hline
\end{tabular}

In Table 6, the results of the complete sample test showed a positively significant relationship between the four variables (BD, AI, OM, and CUS) and DT, but a significant difference was found between the genders, in which three variables (AI, OM, and COM) affected DT in men compared to women with only one variable (CUS). 
GENERAL MANAGEMENT

\begin{tabular}{|l|l|l|l|}
\hline R square & 0.65 & 0.752 & 0.396 \\
\hline P-value & $0.000^{* * *}$ & $0.000^{* * *}$ & $0.086^{*}$ \\
\hline $\begin{array}{l}\text { Notes: Significance is statistical at } 10 \%\left({ }^{*}\right), 5 \%\left(^{* *}\right) \text {, and } 1 \%\left(^{* * *}\right) . \text { Const.: Constant. SC: Standardized coefficients. } \\
\text { Obs.: Observation. }\end{array}$ \\
\hline
\end{tabular}

Table 6: Regression results for determinants of digital transformation adoption based on gender Source: Own study

Similarly, both Hanoi City and Ho Chi Minh City were the three variables that influenced DT in Table 7, in which Hanoi City included AI, CUS, and COM, while Ho Chi Minh City was AI,
$\mathrm{OM}$, and COM. In particular, no evidence of impact was found in other places.

\begin{tabular}{|c|c|c|c|c|c|c|c|c|}
\hline \multirow[t]{2}{*}{$\begin{array}{l}\text { Dependent } \\
\text { variable (DT) }\end{array}$} & \multicolumn{2}{|c|}{$\begin{array}{l}\text { Full Sample } \\
\text { (Obs. = 164) }\end{array}$} & \multicolumn{2}{|c|}{$\begin{array}{l}\text { Hanoi City } \\
\text { (Obs. = 43) }\end{array}$} & \multicolumn{2}{|c|}{$\begin{array}{l}\text { Ho Chi Minh City } \\
\text { (Obs. = 102) }\end{array}$} & \multicolumn{2}{|c|}{$\begin{array}{l}\text { Others } \\
\text { (Obs. = 19) }\end{array}$} \\
\hline & SC & P-value & SC & P-value & SC & P-value & SC & P-value \\
\hline Const. $(\alpha 0)$ & & 0.16 & & 0.422 & & 0.153 & & 0.346 \\
\hline $\mathrm{BD}(\alpha 1)$ & 0.147 & $0.017^{* *}$ & 0.061 & 0.727 & 0.134 & 0.090 & -0.048 & 0.821 \\
\hline AR ( $\alpha 2)$ & -0.015 & 0.789 & 0.038 & 0.762 & 0.020 & 0.788 & -0.759 & 0.073 \\
\hline $\mathrm{Al}(\alpha 3)$ & 0.289 & $0.00^{* * *}$ & 0.296 & $0.02^{* *}$ & 0.300 & $0.00^{\star \star \star}$ & 0.156 & 0.601 \\
\hline VR (a4) & 0.074 & 0.226 & -0.103 & 0.444 & 0.113 & 0.177 & 0.090 & 0.647 \\
\hline DMA (a5) & -0.003 & 0.967 & 0.083 & 0.434 & -0.108 & 0.248 & 0.557 & 0.195 \\
\hline SI (a6) & 0.037 & 0.552 & 0.008 & 0.949 & 0.119 & 0.135 & -0.256 & 0.505 \\
\hline $\mathrm{OM}(\alpha 7)$ & 0.235 & $0.00^{* \star *}$ & -0.053 & 0.718 & 0.389 & $0.00^{* * *}$ & -0.239 & 0.268 \\
\hline CUS (a8) & 0.202 & $0.00^{* * *}$ & 0.482 & $0.00^{* * *}$ & 0.126 & 0.113 & 0.346 & 0.328 \\
\hline $\operatorname{COM}(\alpha 9)$ & 0.221 & 0.000 & 0.292 & $0.021^{\text {** }}$ & 0.162 & $0.024^{\star *}$ & 0.438 & 0.154 \\
\hline $\mathrm{CP}(\alpha 10)$ & -0.045 & 0.445 & 0.079 & 0.440 & -0.060 & 0.428 & 0.568 & 0.252 \\
\hline R square & \multicolumn{2}{|l|}{0.65} & \multicolumn{2}{|l|}{0.79} & \multicolumn{2}{|l|}{0.64} & \multicolumn{2}{|c|}{0.88} \\
\hline P-value & \multicolumn{2}{|l|}{$0.000^{\star * \star}$} & \multicolumn{2}{|l|}{$0.000^{* * *}$} & \multicolumn{2}{|l|}{$0.000^{\star * *}$} & \multicolumn{2}{|c|}{$0.009^{\star * *}$} \\
\hline
\end{tabular}

Table 7: Regression results for determinants of digital transformation adoption based on region Source: Own study

Interestingly, the results revealed that there is no statistically significant difference in factors, including gender and region, for the adoption of digital transformation in Vietnamese creative services. However, the gender findings differed considerably from those reported in previous studies (Kwon et al., 2007; Akman and Rehan, 2016; Ramírez-Correa et al., 2019; Chawla and Joshi, 2020), but are in line with Aluri and Palakurthi (2011). Furthermore, the most interesting regression equation was established from the research framework that removed three variables due to their unreliability, such as blockchain (BLO), financial strength (FS), and social community (SC). The most striking observation that emerged from the analysis was the effect of gender and region on the determinants of the adoption of digital transformation in the context of Vietnamese creative services. The results of the factors (BD, Al, VR, AR, and DMA) were first found, but other factors (SI, OM, CUS, COM, and CP) were also explored in gender and region groups. Variables, such as customers in the female and Hanoi city groups and competitors in the male and Ho Chi Minh city groups, which were significant at $5 \%$, are consistent with the study by Tripopsakul (2018); however, the variable of social influence had a converse result in all groups. Similar to the work of Karatepe and Aga (2016), positively significant results of the organizational mission variable were detected, which are in male and Ho Chi Minh city groups. Especially, this study shows that the result of competitive pressure was not significant in all groups, which is appropriate for the study by McKinnie (2016). Nevertheless, these different results can only be partially explained in this study due to the limitation of an unequal sample size between the groups.

\section{Conclusions}

In summary, these results emphasized the importance of gender and region for the adoption of digital transformation, as well as the effect of them on the determinants of digital transformation in the creative services belonging to Vietnam's creative industries. The results reported here confirm that there are no differences between gender and region associated with the adoption of digital transformation. However, the findings, which were from multivariate regression analysis, revealed that there are not many factors that affect the adoption of digital transformation. For example, only four of the ten factors in the entire sample, including big data capture and analytics (BD), artificial intelligence ( $\mathrm{Al})$, organizational mission (OM), and customer (CUS), impacted the adoption of digital transformation compared to the results of other separate groups. This study has underlined the significance of gender and region in the context of the research area and contributes to enriching the issues of digital transformation in Vietnam's creative services, especially the creative enterprises operating in this industry. Furthermore, this work can be helpful at the management level, recognize and focus on other factors that can influence the progress of digital transformation of creative companies, such as augmented reality (AR), virtual reality (VR), and digital marketing and online advertising (DMA) because these modern technological elements are trendy and have been popularly applied in creative industries in general. Competitive pressure should be more centralized because this factor will have a direct and indirect influence on businesses in the market; therefore, when weaknesses are overcome, they also contribute to promoting the development of creative firms based on investment effectiveness, improving governance capacity, and recognition 
of possible risks. The most important limitation is the result of the fact that surveyors are a representation of businesses in creative services, and the sample distribution of research data is not equal between the separate groups, which can also affect the reliability of the study results. Further research is needed to investigate the larger sample size in this area or other areas in the creative industries, as well as consider applying this research framework with other demographic variables for various studies.

\section{References}

[1] Akman, I., \& Rehan, M. (2016). Examination of factors influencing employees' adoption of mobile commerce and services in Turkey. Economic Research-Ekonomska Istraživanja, 29(1), 770-781. doi:10.1080/1331677x.2016.1197552

[2] Al Hadwer, A., Tavana, M., Gillis, D., \& Rezania, D. (2021). A Systematic Review of Organizational Factors Impacting Cloudbased Technology Adoption Using Technology-OrganizationEnvironment Framework. Internet of Things, 15, 100407. doi:10.1016/j.iot.2021.100407

[3] Aluri, A., \& Palakurthi, R. (2011). The influence of demographic factors on consumer attitudes and intentions to use RFID technologies in the US hotel industry. Journal of Hospitality and $\begin{array}{lll}\text { Tourism } & \text { Technology, } & \text { 188-203. }\end{array}$ doi:10.1108/17579881111173749

[4] Chandra, S., \& Kumar, K. N. (2018). Exploring factors influencing organizational adoption of augmented reality in $\mathrm{e}$ commerce: Empirical analysis using technology-organizationenvironment model. Journal of Electronic Commerce Research, 19(3), 237-265. Retrieved from: http://www.jecr.org/sites/default/files/2018vol19no3_paper3.pd f.

[5] Chatterjee, S., Rana, N. P., Dwivedi, Y. K., \& Baabdullah, A. M. (2021). Understanding Al adoption in manufacturing and production firms using an integrated TAM-TOE model. Technological Forecasting and Social Change, 170, 120880. doi:10.1016/j.techfore.2021.120880

[6] Chawla, D., \& Joshi, H. (2020). The moderating role of gender and age in the adoption of mobile wallet. Foresight, 22(4), 483504. doi:10.1108/fs-11-2019-0094

[7] Chen, L., Gillenson, M. L., \& Sherrell, D. L. (2002). Enticing online consumers: an extended technology acceptance perspective. Information \& Management, 39(8), 705-719. doi:10.1016/s0378-7206(01)00127-6

[8] Davis, F. D. (1989). Perceived Usefulness, Perceived Ease of Use, and User Acceptance of Information Technology. MIS Quarterly, 13(3), 319. doi:10.2307/249008

[9] Hair, J. F., Black, J. W. C., Babin, B. J., \& Anderson, R. E. (2010). Multivariate Data Analysis, Pearson Prentice Hall. doi: 10.1111/j.1467-9574.1962.tb01184.x.

[10] Harris, M., Cox, K. C., Musgrove, C. F., \& Ernstberger, K. W. (2016). Consumer preferences for banking technologies by age groups. International Journal of Bank Marketing, 34(4), 587602. doi:10.1108/ijbm-04-2015-0056

[11] Hwang, B.-N., Huang, C.-Y., \& Wu, C.-H. (2016). A TOE Approach to Establish a Green Supply Chain Adoption Decision Model in the Semiconductor Industry. Sustainability, 8(2), 168. doi:10.3390/su8020168

[12] Karatepe, O. M., \& Aga, M. (2016). The effects of organization mission fulfillment and perceived organizational support on job performance. International Journal of Bank Marketing, 34(3), 368-387. doi:10.1108/ijbm-12-2014-0171
[13] Ju Kwon, H., Joshi, P., \& Prier Jackson, V. (2007). The effect of consumer demographic characteristics on the perception of fashion web site attributes in Korea. Journal of Fashion Marketing and Management: An International Journal, 11(4), 529-538. doi:10.1108/13612020710824580

[14] Liu, D., \& Guo, X. (2016). Exploring gender differences in acceptance of mobile computing devices among college students. Information Systems and e-Business Management, 15(1), 197-223. doi:10.1007/s10257-016-0315-x

[15] Mckinnie, M. (2016). Cloud Computing: TOE Adoption Factors By Service Model In Manufacturing (Doctoral dissertation). Georgia State University. Retrieved from: http://scholarworks.gsu.edu/bus_admin_diss/68

[16] Naqvi, M., Li, S., Jiang, Y., \& Naqvi, M. H. A. (2019). The rise of social networking sites. Asia Pacific Journal of Marketing and Logistics, 32(1), 232-252. doi:10.1108/apjml-01-2019-0029

[17] Porter, C. E., \& Donthu, N. (2006). Using the technology acceptance model to explain how attitudes determine Internet usage: The role of perceived access barriers and demographics. Journal of Business Research, 59(9), 9991007. doi:10.1016/j.jbusres.2006.06.003

[18] Ramírez-Correa, P. E., Grandón, E. E., \& Arenas-Gaitán, J. (2019). Assessing differences in customers' personal disposition to e-commerce. Industrial Management \& Data Systems, 119(4), 792-820. doi:10.1108/imds-07-2018-0280

[19] Ritz, W., Wolf, M., \& McQuitty, S. (2019). Digital marketing adoption and success for small businesses. Journal of Research in Interactive Marketing, 13(2), 179-203. doi:10.1108/jrim-04-2018-0062

[20] Schober, P., Boer, C., \& Schwarte, L. A. (2018). Correlation Coefficients. Anesthesia \& Analgesia, 126(5), 1763-1768. doi:10.1213/ane.0000000000002864

[21] Tornatzky, L.G., \& Fleischer, M. (1990). The processes of technological innovation. Lexington books, Lexington, MA. doi: 10.1007/BF02371446.

[22] Trieu, T. V. H., \& Pavelková, D. (2020). Digital transformation and its influence on performance of creative industry companies. ICFE 2020 - The 6th International Conference on Finance and Economics, 83-98. Retrieved from: https://www.researchgate.net/profile/Thierry-

Tartarin/publication/349339689 COVID-

19_IMPACT_ON_BUSINESS_MODELS_AND_BUSINESS_P RACTICES_RESULTS_FROM_AN_INTERNATIONAL_ONLI NE_SURVEY/links/602bb7984585158939a99995/COVID-19IMPACT-ON-BUSINESS-MODELS-AND-BUSINESSPRACTICES-RESULTS-FROM-AN-INTERNATIONALONLINE-SURVEY.pdf\#page $=99$

[23] Tripopsakul, S. (2018). SOCIAL MEDIA ADOPTION AS A BUSINESS PLATFORM: AN INTEGRATED TAM-TOE FRAMEWORK. Polish Journal of Management Studies, 18(2), 350-362. doi:10.17512/pjms.2018.18.2.28

[24] Ullah, F., Qayyum, S., Thaheem, M. J., Al-Turjman, F., \& Sepasgozar, S. M. E. (2021). Risk management in sustainable smart cities governance: A TOE framework. Technological Forecasting and Social Change, 167, 120743. doi:10.1016/j.techfore.2021.120743

[25] UNCTAD (2008). Creative Economy Report 2008. The Challenge of Assessing the Creative Economy: towards Informed Policy-making, United Nations. doi: 10.1016/j.respol.2005.04.009

[26] Venkatesh, Morris, Davis, \& Davis. (2003). User Acceptance of Information Technology: Toward a Unified View. MIS Quarterly, 27(3), 425. doi:10.2307/30036540 